\title{
Süt Ürünlerinde Serum Protein İzolatı Kullanımı
}

\author{
Filiz YILDIZ AKGÜL"', Ayşe Demet KARAMAN' \\ 'Adnan Menderes Üniversitesi, Ziraat Fakültesi, Süt Teknolojisi Bölümü, AYDIN.
}

Özet: Son yıllarda, peynir altı suyundan elde edilen serum proteinleri içerdikleri besleyici ve fonksiyonel proteinler ve peptidler nedeniyle çeşitli gıda maddelerinde ürünün fonksiyonel ve biyolojik değerlerini arttırmak ve geliştirmek üzere kullanılmaktadır. Özellikle serum protein izolatları (Whey Protein Isolate, WPI) yüksek oranda serum proteinlerini, düşük oranda ise laktoz ve yağı içermeleri nedeniyle yağı azaltılmış yoğurt üretiminde kullanımı geniş yer tutmaktadır. Ultrafilitrasyon, kristalizasyon ve ters ozmoz gibi çeşitli yöntemlerle elde edilen WPI'nın süt teknolojisinde kullanımı her geçen gün artmaktadır. Bu makalede incelenen literatür bilgilerine göre, süt ürünlerinde WPI'nın kullanım amaçları ve ürünler üzerindeki fonksiyonel etkileri irdelenmiştir.

Anahtar Kelimeler: serum proteinleri, WPI, fonksiyonel özellik, süt ürünleri

\section{The Usage of Whey Protein Isolate in Dairy Products}

Abstract: Serum proteins got from whey have been used in recent years to enhance and improve the functional and biological properties of various food products due to the nutritive and functional proteins and peptides they contain. In particular, whey protein isolates (WPI) use to product in reduced fat yoghurt as have high levels of serum proteins and low levels of lactose and fat. As the WPI obtained by various methods such as ultrafiltration, crystallization and reverse osmosis, usage rate in dairy technology is increasing day by day. According to the literature, reviewed in this article, the usage of WPI in dairy products and the functional effects on products are examined.

Keywords: whey protein, WPI, functional properties, dairy products

\section{GíRiş}

Serum proteinleri toplam süt proteininin \%20'sini oluşturmaktadır ve peynir üretimi sırasında peyniraltı suyuna geçmektedir. Peyniraltı suyunda başta $\beta$-laktoglobulin ve $\alpha$-laktalbumin olmak üzere, immunoglobulünler ve serum proteinleri gibi çeşitli proteinler ile enzimler ve hormonlar bulunmaktadır. Serum proteinleri genel olarak, peyniraltı suyu tozu, serum protein konsantratı (WPC) ve serum protein izolatı (WPI) şeklinde üretilmektedir (Mathew ve KrishnaMurthy, 2013). Konsantre edilmiş bu protein formlarında serum proteinleri oranı yüksek iken laktoz ve yağ gibi bileşenlerin oranı daha düşüktür ( $\mathrm{Pal}$ ve Radavelli-Bagatini, 2013). Son yıllarda serum proteinlerinin üretimi ve gıdalarda bileşen olarak kullanımı artmaktadır.

Yapılan çalışmalarda serum proteinlerinin çeşitli gıdalarda farklı amaçlarla kullanıldığı görülmektedir. Laktoz intoleransı veya vejetaryen olan kişiler için ürünün tüketicilerin sağlığı üzerinde etkileri arttırılabilmektedir. Ayrıca yağ gibi gıdanın temel bileşenlerinin uzaklaştırılmasında ürünün yapısal ve tekstürel özelliklerinin iyileştirilmesinde de kullanılmaktadır. Maliyetinin düşük olması nedeniyle üretim ve hammadde maliyetlerinin düşürülmesi amacıyla gıda işletmecileri tarafından da tercih edilmektedir (Krolczyk ve ark., 2016).

Peyniraltı suyu tozu ve serum protein konsantratları süt ürünlerinde çeşitli amaçlarla oldukça fazla kullanılmaktadır ve bu alanda yapılmış pek çok çalışma bulunmaktadır. WPI için de çeşitli süt ürünlerinde uygulamaları mevcuttur. Ancak incelenen literatür çalışmalarında, serum proteini izolatlarının süt ürünlerinde kullanımına yönelik araştırmaların çok az olduğu görülmüştür. Bu nedenle bu derlemede, WPI'nın süt ürünlerinde kullanım alanları ve ürünler üzerindeki fonksiyonel etkileri mevcut literatür çalışmaları göz önünde bulundurularak bir araya getirilmeye çalışılmıştır.

\section{SERUM PROTEIN IZOLATLARININ} BILEŞiMi ve TEKNOLOJisi

Peyniraltı suyu, sütün peynire işlenmesi sırasında elde edilen sarımtırak-yeşil renkli yan üründür. Genellikle ekşi ve tatı peyniraltı suyundan elde edilmektedir. Bileşiminde makro düzeyde $\beta$-laktoglobulin ve $\alpha$-laktalbumin ve mikro düzeyde glikomakropeptidler, fosfolipoproteinler, laktoferrin ve transferrin bulunmaktadır. Ayrıca çok sayıda enzim ve biyoaktif maddeleri içermektedir (Dinçoğlu ve Ardıç, 20।2; Karagözlü ve Bayarer, 2004). Bununla beraber peyniraltı suyunda sı̆̆ır serum albumini, immunoglobulinler, proteteoz-peptonlar, laktoz ve riboflavin, folik asit ve kobalamin olmak üzere suda çözünen vitaminler, bazı mineral maddeler ve laktoperoksidaz da bulunmaktadır (Yerlikaya ve ark., 20I0). Bu nedenle oldukça zengin biyolojik özelliklere sahip peyniraltı suyunun ekonomiye kazandırılması gerekmektedir. Ayrıca peyniraltı suyu, peynir işleyen firmalar için çevre kirliliği açısından büyük bir sorundur. Peyniraltı suyunun direk çevreye verilmesi yasaktır. Bu bakımdan da peyniraltı suyu değerlendirildiğinde, hem süt teknolojisi açısından hem de çevre açısından önemli yan ürünler ortaya çıkmaktadır.

Serum proteinleri yüksek biyolojik değere sahip olup, lösin, izolösin, valin ve sistein gibi dallanmış zincirli aminoasit içermeleri nedeniyle vücutta proteine ve enerjiye çevrilme oranları oldukça yüksektir (Özen ve Kılıç, 2007). Ayrıca hızlı sindirilebilir olduklarından, vücuda alımlarını takiben serumdaki amino asit miktarlarının hızlıca artmasına neden olurlar (Ramos ve ark., 2016). Bununla beraber serum proteinleri insan sağlığı üzerinde de oldukça önemli fonksiyonlara sahiptir. Sağlık üzerine olan etkilerine ait özellikler Çizelge I'de verilmiştir. Serum proteinleri içerisinde en fazla miktarda bulunan $\beta$ laktoglobulin (\%50) yeni doğan memelilerde pasif bağışıklığın taşınmasında, meme bezinde fosfor metabolizmasının düzenlenmesinde etkilidir. $\mathbf{\alpha}$-Laktalbumin ise laktozun biyosentezinde rol almaktadır (Farrel ve Bede, 1987; Fox, 1989). $\beta$-laktoglobulin, yüksek oranda sistein amino asidi içermesinden dolayı kasların gelişiminde fonksiyonu vardır. $\mathbf{\alpha}$-Laktalbumin göğüs ve kolon kanseri hücrelerinin parçalanmasında etkili olup

*Sorumlu Yazar: filiz.yildiz@adu.edu.tr

Geliş Tarihi: 29 Mart 2017

Kabul Tarihi: 24 Mayis 2017 
Çizlege I. Serum proteinlerinin biyolojik fonksiyonları ve sağlık üzerine etkileri (Ramos ve ark., 20।6)

\begin{tabular}{|c|c|c|}
\hline Serum proteini & Biyolojik fonksiyon & Sağlık üzerine etkisi \\
\hline$\beta$-laktoglobulin & $\begin{array}{l}\text { Memelilerde pasif bağışıklık sağlamak, } \\
\text { Meme bezinde fosfor metabolizmasını düzenlemek, } \\
\text { Retinol, palmitat, vitamin D, kolestrol, serbest yağ asidi, } \\
\text { trigliseritleri taşımak }\end{array}$ & $\begin{array}{l}\text { Bağırsaklardan lipit emilimini düşürmek } \\
\text { Antikarsinojenik etki } \\
\text { Pasif bağışılık sistemini geliştirmek } \\
\text { Immunomodülatör etki }\end{array}$ \\
\hline Laktalbümin & Laktozun biyosentezini etkilemek & $\begin{array}{l}\text { Antikarsinojenik etki } \\
\text { Kemik gelişiminde etki } \\
\text { Kronik stres hastalıklarında tedavi }\end{array}$ \\
\hline Sığır serum albumini & Serbest yağ asitlerini ve lipitleri bağlamak ve sentezlemek & $\begin{array}{l}\text { Bağırsaklardan lipit emilimini düşürmek } \\
\text { Antioksidant etki } \\
\text { Antikarsinojenik etki } \\
\text { Antimutajenik etki }\end{array}$ \\
\hline $\begin{array}{l}\text { Laktoferrin } \\
\text { Laktoperoksidaz }\end{array}$ & $\begin{array}{l}\text { Demir bağlamak } \\
\text { Enterik bakterileri yok etmek }\end{array}$ & $\begin{array}{l}\text { Antimikrobiyal, antiviral, antifungal, antitrombotik etki } \\
\text { Antimikrobiyal, antifungal ve antioksidan etki }\end{array}$ \\
\hline Immunoglobulin G & Pasif bağışıklık & $\begin{array}{l}\text { Bağışılklık sistemini güçlendirmek } \\
\text { Antifungal etki } \\
\text { Antibakteryel etki }\end{array}$ \\
\hline Serum proteinlerinin çoğunluğu & $\begin{array}{l}\text { Biyoaktif özellik gösteren serofin, laktoferroksin, alfa-laktorfin, } \\
\text { beta-laktorfin, latotensin oluşması }\end{array}$ & $\begin{array}{l}\text { Opioid etki } \\
\text { ACE inhibe edici etki } \\
\text { Antihipertansif etki }\end{array}$ \\
\hline
\end{tabular}

antikarsinojenik etki göstermektedir (Ramos ve ark., 2016). Sığır serum albumini ve $\beta$-laktoglobulin serbest yağ asitlerini ve lipitleri bağlayan proteinlerdir (De Wit, 1998). Laktoferrin demir bağlayıcı bir protein olup antimikrobiyal, antiviral, antifungal etki göstermektedir (Fox, 1989; Shah, 2000). Laktoferrin kemiklerdeki osteoklastları engeller ve böylece kemik ana hücrelerinin gelişiminde, osteoblast oluşumunda etkili olup, kemik gelişimini güçlendirmektedir (Ramos ve ark., 20I6). Laktoperoksidaz enterik bakterileri yok ederek yeni doğanlarda patojen mikroorganizmalara karşı korunma sağlar ve ayrıca antioksidan fonksiyon gösterir (Shah, 2000; Çankaya ve ark., 2006; Yerlikaya ve ark., 20l0).

Ayrıca serum proteinlerinin yoğurt ve peynir gibi fermente süt ürünlerinde kullanımında üretim esnasında ya da sindirim esnasında serofin, laktoferroksin, alfa-laktorfin, beta-laktorfin ve laktotensin gibi biyoaktif özellik gösteren peptidler oluşmaktadır (Korhonen ve ark, 1998). Biyoaktif peptidlerin kalp-damar sistemi reaksiyonlarında risk faktörlerinden olan antiyotensin dönüştürücü enzimi (ACE) inhibe edici ve antihipertansif etki gösterdiği belirtilmektedir (Gürsoy ve ark., 20I5). Bununla beraber Laktoglobulin, a-laktalbumin, immunoglobulin ve laktoferrin gibi serum proteinlerinin büyük çoğunluğunun in vitro ve in vivo koşullarda antioksidan, antihipertansif, antitümör, antiviral ve antibakteriyel ajan olarak etkili olduğu da belirtilmektedir (Sousa ve ark., 20I2)

Peyniraltı suyu, bu bakımdan dünyada ve ülkemizde küçük işletmelerde de dahil olmak üzere çeşitli şekillerde değerlendirilmesi ekonomik açıdan ve biyoçeşitliliğin korunması açısından önemli olmaktadır. Peyniraltı suyundan, konsantre peyniraltı suyu, peyniraltı suyu tozu, serum protein konsantresi, serum protein izolatı ve laktoz gibi çeşitli ürünler üretilmektedir. Peyniraltı suyu ürünleri günümüzde gıda, tıp, biyogaz üretimi, eczaclık, kozmetik gibi pek çok alanda kullanılmakta olup gıda ürünlerinde yapısal özellikleri iyileştirmek veya biyolojik aktiviteye sahip peptid fraksiyonları elde edilmesinde kullanılmaktadır (Alpkent ve Göncü, 2003; Özen ve Kilıç, 2007).

Peyniraltı suyu tozu \% II-13 protein, serum protein konsantratları \%34-98 protein ve serum protein izolatları ise $>\% 90$ protein içermektedir (Davis ve Foegeding, 2007). Protein içeriği minimum \%90 olan WPl' larda çok düşük düzeyde yağ (\%I), laktoz (\%I) ve mineral madde (\%3) bulunmaktadır (Yerlikaya ve ark., 2010). Ayrıca WPI'lar biyolojik olarak değerlendirilebilen mükemmel bir kalsiyum ve mineral kaynağıdırlar (Ha ve Zemel, 2003).

Serum proteinlerinin izolasyonunda ısıl işlem ile denatürasyon ve asit etkisiyle presipitasyon kullanılan en eski tekniklerden birisidir. Bu geleneksel tekniklerle üretilen ürün denatüre formda elde edildiği için suda çözünememekte ve fonksiyonel özelliklerini yerine getirememektedir. Bu nedenle doğal serum proteinlerinin özelliklerine en yakın serum protein eldesi için ultrafiltrasyon, jel filtrasyonu, karboksimetil selüloz kompleksinin presipitasyonu gibi tekniklerden yararlanılmaktadır (Gürsel, 2007). Bu teknikler elektrodiyaliz ve laktoz kristalizasyonu ile genellikle bir arada yürütülmektedir (Gürsel, 2007).

WPI, laktoz ve yağın uzaklaştırılıp protein oranının \%90'nın üzerine çıkarılması, iyon değiştirici kromotografisi ya da mikrofiltrasyon olmak üzere iki farklı yol ile elde edilmektedir. lyon değiştirici yönteminde, peyniraltı suyu proteinlerinin iyon değiştiricide tutulurken mikrofiltrasyon yönteminde ise peyniraltı suyu uygun membran (gözenek çapı $<$ l $\mu \mathrm{m}$ ) kullanılarak diğer süt bileşenlerinden ayrılmaktadır. Bu yöntemlerle elde edilen permetta çok az miktarda protein kalmaktadır. Iyon değiştirici kullanılarak üretilen WPI'lar, mikrofiltrasyon yöntemiyle üretilen WPI'lara göre daha düşük oranda kazein ve glikomakropeptid içermektedir (Foegeding ve ark., 2003; El-Salam ve ark., 2009; Lagrande ve ark., 20I5).

\section{SERUM PROTEIN IZOLATLARININ FONKSIYONEL ÖZELLIKLERi}

Serum proteinlerinin çözünürlük, köpük, jel, emülsiyon ve lif oluşturma, su bağlama, kıvam verme gibi çeşitli fonksiyonel özelliklerinin bulunmasından dolayı gıda ve süt teknolojisinde ürünlerin duyusal ve tekstürel özelliklerini iyileştirmek ve dayanıklıı̆ı artıımak amacıyla kullanılmaktadır. Bununla beraber serum protein konsantrat ve izolatları, üretim teknolojisi bakımından ısı işlem görmediği için, denatüre serum proteinlerini içermemekte ve dolayısıyla su tutma kapasiteleri artmaktadır. Bu nedenle yoğurt ve benzeri fermente ürünlerin üretiminde kullanım alanı bulmaktadır (De Wit, 1998; Mleko ve Gustaw, 2002). 
Çizelge 2. Süt ürünlerinde WPI uygulamaları

\begin{tabular}{|c|c|c|c|}
\hline Ürün & WPI kullanım amacı & Etkisi/fonksiyonel özellik & Kaynak \\
\hline Yoğurt & Yapıyı iyileştirmek & $\begin{array}{l}\text { Sinerezde azalma, } \\
\text { daha iyi kalitede mikroyapı. }\end{array}$ & Shi ve ark., 2017 \\
\hline Yoğurt & $\begin{array}{l}\text { Yapıyı iyileştirmek } \\
\text { Besin değerini arttırmak }\end{array}$ & $\begin{array}{l}\text { Fizikokimyasal ve duyusal, } \\
\text { özelliklerini olumlu yönde etki. }\end{array}$ & Bagcı ve Gunasekaran, 2016 \\
\hline Yoğurt & Yapıyı iyileştirmek & $\begin{array}{l}\text { Yüksek protein oranı, } \\
\text { daha iyi yoğurt jel oluşumu, daha beyaz renk, duyusal } \\
\text { özelliklerde beğenilme. }\end{array}$ & Delikanlı ve Özcan, 2014 \\
\hline Yoğurt & $\begin{array}{l}\text { Ürünün besin değerini arttırmak ve yapısal } \\
\text { özellikleri iyileştirmek } \\
\text { Yeni nesil süt ürünleri geliştirilmesi }\end{array}$ & $\begin{array}{l}\text { Yapısal ve aroma bileşenlerinde katkı, post- } \\
\text { asidifikasyon riskini düşürme, toplam fermantasyon } \\
\text { süresinde azalma. }\end{array}$ & Hugunin ve Lucey, 2009 \\
\hline Yoğurt & Yapıyı iyileştirmek & $\begin{array}{l}\text { Konsistens ve mikroyapı üzerine olumlu etki, daha az } \\
\text { yapışkan yapı. }\end{array}$ & Guggisberg ve ark., 2007 \\
\hline Yoğurt & Yapıyı iyileştirmek & $\begin{array}{l}\text { Sinerez oranında azalma, viskozitede artış, } \\
\text { Mikroyapıda iyileşme. }\end{array}$ & Matumoto-Pintro ve ark., 20I I \\
\hline Yoğurt & Yapıyı iyileştirmek & Sertlikte artış, tam yağlı yoğurt yapısı & Kreminski ve ark., 201 I, \\
\hline Yoğurt & Yapıyı iyileştirmek & Reolojik yapının iyileşmesi & Patocka ve ark., 2006 \\
\hline Yoğurt içecekleri & Jel yapısını iyileştirmek & Jel oluşumunda gelişme, jel reolojisinin gelişimi. & Walsh-O'Grady ve ark., 2001 \\
\hline Gelato dondurma & $\begin{array}{l}\text { Üretim maliyetlerini düşürmek, } \\
\text { Yapıyı iyileştirmek }\end{array}$ & $\begin{array}{l}\text { Ürün sertliğinde artış, işletme maliyetlerinin } \\
\text { azaltılması, yüksek kalitede dondurma. }\end{array}$ & Alsaifi ve Estathopoulos, 2010 \\
\hline $\begin{array}{l}\text { Dondurma } \\
\text { Meyveli Dondurma (Sundae) }\end{array}$ & $\begin{array}{l}\text { Üretim maliyetlerini düşürmek, } \\
\text { Yapıyı iyileştirmek }\end{array}$ & Besin değerinde, kıvam ve kalitede artış. & Young, 2007 \\
\hline Peynir & $\begin{array}{l}\text { Üretim maliyetlerini düşürmek, } \\
\text { Ürün kalitesinin iyileştirilmesi, } \\
\text { Proses ve depolama aşamasındaki hataların } \\
\text { azaltılması }\end{array}$ & $\begin{array}{l}\text { Kritalizasyonun önlenmesi, ürünün esmerleşmesinin } \\
\text { önlenmesi, randıman artışı, ürün bileşen } \\
\text { maliyetlerinde düşüş. }\end{array}$ & Young 1999 \\
\hline
\end{tabular}

Süt proteinlerinin fonksiyonel özellikleri üç farklı grupta toplanmaktadır. Protein-su interaksiyonu ile ilgili özellikleri; proteinlerin yüksek çözünürlük, su tutma kapasitesini sağlama ve viskozite iyileşmesine bağlı olarak yağ partiküllerinin yapıda tutulmasına ve emülsiyon özelliklerinin iyileşmesine neden olmaktadır. Peyniraltı suyu protein izolatları yağlarda lesitin ile kullanıldığında emülsiyon özelliğini arttırmaktadır. Dolayısıyla süt ürünlerinde ve özellikle sürülebilir krem peyniri üretiminde kullanılmaktadır. Protein-protein interaksiyonu ile ilgili olan özellik ise tekstürel özellikler olup, protein jelleşmesi, katı viskoelastik jel oluşumu ve pıhtılaşma bu özellikler arasında yer almaktadır. Proteinlerin-hava interaksiyonu ile ilgili olan özellikleri ise emülsiyon oluşturma, köpük oluşturma ve tat ve aroma bağlamadır. Bu özellikleri ile süt proteinleri emülgatör olarak süt ürünlerinde katkı maddesi, köpürme özellikleri nedeniyle fonksiyonel bileşen olarak kullanılmaktadır. Ayrıca gıdalardaki aldehit, keton, esterler gibi çeşitli aroma bileşikleri ile reaksiyona girerek veya bu bileşenlerin proteine bağlanması yolu ile gıdalara istenilen tat ve koku özellikler de kazandırılabilmektedir (Özcan ve Delikanlı, 20 I I).

\section{SÜT ÜRÜNLERINDE WPI KULLANIM ALANLARI}

Günümüzde gelişen teknoloji ve yapılan bilimsel çalışmalar sonucunda, fermente süt ürünlerinde WPI kullanımına yönelik uygulamalar son yıllarda artmaktadır. Süt ürünlerde WPI kullanımına ilişkin çalışmalara ait literatür özeti Çizelge 2'de görülmektedir.

Yoğurt kalitesini iyileştirmek, proteince zenginleştirmek, yoğurtta sinerez oranını düşürmek üzere yapılan bir çalışmada, süt proteinlerin arasındaki çapraz bağlanmayı (crosslinking) arttırmak üzere yoğurt üretiminde transglutaminaz ve termal polimerizasyon uygulanmış WPI kullanılmıştır. Çalışma sonunda genel olarak WPI kullanımının yoğurttaki sinerez oranını azalttığı ve daha iyi kalitede mikroyapı oluşturduğu tespit edilmiştir (Shi ve ark., 2017).

Bagcı ve Gunasekaran (2016) yaptıkları çalışmada, 3 farklı oranda demirce zenginleştirilmiş WPI (WPI-Fe) kullanımının yoğurdun fizikokimyasal ve duyusal özelliklerini 14 günlük depolama boyunca olumlu yönde etkilediğini tespit etmişlerdir. Bu nedenle araştırmacılar tüketici beklentilerinin karşılanmasında alternatif olarak demirce zenginleştirilmiş WPI kullanımının mümkün olabileceğini belirtmişlerdir.

Delikanlı ve Özcan (20 |4), yağsız süt ürünlerinde ve yoğurtlarda görülen zayıf yapı, sineres gibi bazı yapısal özellikleri iyileştirmek için serum protein izolatı (WPI), serum protein konsantratı (WPC) ve serum protein hidrolizatı (WPH) katkılı yağsız yoğurt üretmişlerdir. WPI katkılı yoğurtların protein oranının en yüksek olduğunu, daha iyi yoğurt jel oluşumuna bağlı olarak daha beyaz renk ve örneklerin en yüksek $L$ değerine sahip olduğunu belirtmişlerdir. Aynı araştırmacılar, WPI katkılı yoğurt örneklerinin diğer protein katkılı yoğurt örneklerine nazaran duyusal analiz sonuçlarının (yapı, aroma, tat, genel beğeni) en yüksek değerlerde olduğunu da bildirmişlerdir.

Peyniraltı suyu tozu (SWP), serum proteini konsantratı (WPC) ve serum proteini izolatının (WPI) yoğurt üretiminde kullanıldığı bir çalışmada, WPI kullanımının ürünün yapısal ve aroma bileşenlerine katkıda bulunduğu, özellikle kolay çözünebilirlik, yüksek oranlarda kullanımında dahi kolaylıkla karışabilme özelliğinden dolayı diğer serum proteinlerine göre üstün özellikler gösterdiği belirlenmiştir. Benzer şekilde düşük oranda laktoz içerdiğinden WPI katkılı yoğurtlarda, post-asidifikasyon oluşma riski azalmıştır. WPI'nın düşük miktarlarda kül ve mineral madde içermesi, yoğurtun tamponlama kapasitesini düşürerek yoğurttaki toplam fermantasyon süresini de azalttığı bildirilmiştir (Hugunin ve Lucey, 2009). 
Guggisberg ve ark., (2007) yoğurt üretiminde 5 farklı oranda WPl'yı yoğurt fermantasyonu öncesinde ilave etmişlerdir. Bu durumda yoğurtlarda WPI ilavesinin, kontrol örneği ile karşılaştırıldığında, daha zayıf yapıda yoğurt oluşumuna neden olduğu, kıvamda fark edilebilir bir azalma meydana getirdiği tespit edilmiştir. WPI ilavesinin set tipi yoğurtların konsistens ve mikroyapısını etkilediğini ve daha az yapışkan yapının gözlendiğini bildirmişlerdir.

Farklı peyniraltı suyu proteinleri ve WPI içeren protein formülasyonları ile hazırlanan set ve stirred (pıhtısı kırılmış) tipi yoğurt örnekleri kontrol örneği ile karşılaştırıldığında, WPI kullanımının yoğurtlarda sinerez oranını düşürdüğü, viskoziteyi artırdığı görülmüştür. Araştırmacılar, aynı zamanda set ve stirred tipi yoğurtlarda yoğurt mikroyapısının iyileştiğini ve kompakt gel matriksi oluşumunun arttığını bildirmişlerdir (Matumoto-Pintro ve ark., 20I I).

Kreminski ve ark. (20I I), farklı yağ ve protein oranlarına sahip serum proteini izolatları (WPI) ile zenginleştirilmiş yağ oranı azaltılmış yoğurtlarda yaptıkları çalışmada yoğurt örneklerinin mikroyapısını ve makroyapısını incelemişlerdir. Araştırmacılar, farklı yağ ve protein oranlarındaki yağ oranı düşürülmüş yoğurt örneklerinde WPI kullanımının, ürünlerin sertliğini arttırdığını ve tam yağlı yoğurt özelliklerine yakın özellikle ürün elde edildiğini saptamışlardır.

Fermantasyon öncesi ve fermantasyon sonrası olmak üzere iki farklı zamanda eklenen farklı WPI oranlarında hazırlanmış olan yoğurt örneklerinde yapılan araştırmada, fermantasyon öncesi \%6'dan daha az miktarda ilave edilen yoğurt örneklerinin, reolojikyapısının ticari yoğurt yapısına benzediği belirtilmiştir. Bu araştırmada bu nedenle \%6 dan daha az oranda fermantasyon öncesi WPI ilavesinin yoğurdun reolojik özelliklerinde olumlu etki yarattığı ve ticari olarak uygulanabileceği belirtilmiştir (Patocka ve ark., 2006).

Doğal, basınç ve sıcaklık uygulanmış olmak üzere üç farklı kombinasyonda WPI ile hazırlanmış yoğurt içeceklerinde yapılan bir araştırmada, ısıl işlem uygulamalarının kazeinserum proteinleri arasındaki interaksiyonu arttırdığı ve bu nedenle asidifikasyona bağlı olarak jel oluşumunun arttığını belirtmişlerdir. Araştırmacılar bu nedenle ısıl işlem uygulanmasının ve 500 Pa'dan az basınç uygulamalarının serum proteinlerinin denatürasyonu, jel oluşumunda ve jel reolojisinin gelişiminde önemli aşamalar olduğunu belirtmişlerdir (WalshO'Grady ve ark., 200I).

İki farklı oranda yumurta sarısı (\%5.5 ve \%9) içeren Gelato tipi vanilyalı dondurma üzerine WPI'nın etkisi araştırılmıştır. WPI katkılı ve WPI katsız hazırlanan 10 farklı örnekte, WPI miktarının artışına bağlı olarak dondurmaların sertliğinde bir artış meydana geldiği tespit edilmiştir. Bu nedenle de Gelato tipi dondurma üretiminde işletme maliyetlerinin azaltılması ve yüksek kalitede dondurma üretimi için yumurta sarısı yerine WPI'nın kullanımının uygun olabileceği görüşü araştırmacılar tarafından bildirilmiştir (Alsaifi ve Estathopoulos, 20l0).

Dondurma ve meyveli dondurma (sundae) üretiminde WPI uygulamaları da mevcuttur. Dondurma üretiminde WPI kullanımının dondurmada olgunlaşma boyunca daha hidratasyon oluşmakta ve bu durum miskin kalitesini ve mix performansını etkilemektedir. WPI kullanımı, dondurma üretiminde dondurmada besin değerinin kıvam ve kalitenin artmasına neden olur, ayrıca aynı zamanda bu kalite özellikleri düşük maliyetli bileşenlerin kullanımı ile sağlanabilmektedir. WPI, kullanımı pek tercih edilmeyen bileşen ve katkı maddelerinin kullanımını dondurma üretiminde azalmasını sağlaması açısından da araştırmacılar tarafından kullanımı arzu edilmektedir (Young, 2007).

Young (1999), düşük oranda laktoz içermesinden dolayı peynir üretimi süresince kritalizasyonun önlenmesi ve ürünün esmerleşmesini engellemesi nedeniyle peynir üretiminde WPI kullanımını önermektedir. Aynı araştırmacı, WPI'nın düşük yağ veya karbonhidrat içeren soğuk veya sıcak paketli gıdaların kullanımında uygun olduğunu, bu nedenle peynir üretiminde son ürünün randımanını arttırmak ve ürün bileşen maliyetlerini düşürmek için kullanılabilecek bileşenlerden biri olduğunu da belirtmiştir.

Yapılan çalışmalar irdelendiğinde, WPI kullanımının genellikle yoğurt ve diğer süt ürünlerinde ürünün yapısını iyileştirmek üzere kullanıldığı ve araştırma sonunda beklenen etkilerin görüldüğü tespit edilmiştir. Bununla beraber, ürünün duyusal özellikleri ile ürünün üretim aşamalarında ve son ürünün raf ömrü boyunca kalite özelliklerinde iyileşme görüldüğü de belirlenmiştir (Çizelge 2). Benzer şekilde ürünün randımanında ve üretim maliyetlerinde azalma görülmesi, WPI'nın diğer süt ürünlerinde de uygulama bulması açısından önemli görülmektedir. Diğer taraftan araştırmaların genellikle yoğurt üzerinde gerçekleştirildiği, diğer fermente süt ürünlerinden kefir, konsantre yoğurt ve ayran gibi ürünlerde çalışmaların hiç yapılmadığı dikkat çekmektedir. Aynı zamanda çalışmaların peynir çeşitlerine göre daha detaylı çalışmaların yapılmasını gerektirdiği de görülmektedir (Çizelge 2). Ayrıca çalışmaların genellikle ürünlerin yapısal özelliklerinin iyileştirilmesi amacıyla yapıldığı, WPI kullanılarak üretilen ürünlerin raf ömrü boyunca kalite özelliklerindeki değişimi ve sağlık üzerine etkilerinin irdelenmediği de söylenebilir.

\section{SONUÇ}

Tüketicilerin artan ilgisi ve alandaki gelişmeler doğrultusunda batılı ülkelerde peyniraltı suyu izolatlarının çeşitli gıdalarda ve süt ürünlerde kullanımı yaygınlaşmaktadır. WPI, diğer süt bazlı tozlara oranda daha yüksek protein ve amino asit içermesi, yağ, laktoz ve sodyumu az oranda içermesi nedeniyle düşük kalorili olması, patojenik ve toksik bileşenleri içermemesi, biyo-uyumlu, kullanıma hazır ve ucuz olmasından dolayı süt ürünlerinde kullanımı teknolojinin gelişimine katkı sağlayacaktır. Ancak yapılan bu derleme ile süt ürünlerinde WPI kullanımın birkaç süt ürününde kullanımı dışında kısıtlı kaldığı saptanmıştır. Uygulama alanı geniş ve besleyici değeri yüksek WPI'nın kullanımı teknolojik olarak arttırılması ve sağılı üzerine olumlu etkileri hakkında topluma daha iyi aydınlatılmalıdır.

\section{KAYNAKLAR}

Alpkent Z, Göncü, A (2003) Peynir Suyu ve Peynir Suyu Proteinlerinin Gıda, Kozmetik ve Tıp Alanlarında Kullanılması. Gıda Mühendisliği Dergisi I5: 26-30.

Alsaifi M, Estathopoulus C (2010) Effect of Egg Yolk Substitution by Sweet Whey Protein Isolate on Texture, Stability and Colour of Gelato-Style Vanilla Ice Cream. International Journal of Dairy Technology 63(4): 593-598.

Bagcı OP, Gunasekaran S (2016). Iron-encapsulated cold-set whey protein isolate gel powder-Part 2: Effect of iron fortification on sensory and storage qualities of Yoghurt. International Jornal of Dairy Technology 69(4): 60I-608. 
Çankaya M, Şişecioğlu M, Yörük Ö, Özdemir H (2006) In vitro effects of some antibiotic drugs on bovine lactoperoxidase enzyme. Turk J Med Sci 36 (5): 30I-306.

Davis JP, Foegeding EA (2007) Comparisons of the foaming and interfacial properties of whey protein isolate and egg white proteins. Colloids and Surfaces B: Biointerfaces 54 (2): 200-2I0

Delikanlı B, Ozcan T (2014) Effects of various whey proteins on the physicochemical and textural properties of set type nonfat yoghurt. International Jornal of Dairy Technology 67(4): 495-503.

De Wit JN (1998) Nutritional and functional characteristics of whey proteins in food products.Journal of Dairy Science 81:59-608.

Dinçoğlu AH, Ardıç $M$ (20/2) Peyniraltı Suyunun Beslenmemizdeki Önemi ve Kullanım Olanakları. Harran Üniversitesi Veteriner Fakültesi Dergisi I ( I): 54-60.

El-Salam MH, El-Shibiny S, Salem A (2009) Factors affecting the functional properties of whey protein product. Food Reviews International 25 (3): 25I-270.

Farrell HM, Bede MJ, Enyeart JA (1987) Binding of p-nitrophenyl phosphate and other aromatic compounds by b-Lg. Journal of Dairy Science 70: 252-258.

Foegeding EA, Luck PJ, Roginski H, Fuquay JW, Fox PF (2003) Whey Protein Products. Encyclopedia of Dairy Sciences 3: 1957-1960.

Fox PF (1989) The Milk Protein System. In Developments in Dairy Chemistry. In P.F. Fox (Ed.). Functional Milk Proteins, Volume 4, London: Applied Science.

Gürsel A (2007) Süt Esaslı Ürünler Teknolojisi. Ankara Üniversitesi Ziraat Fakültesi Yayınları, Ankara.

Gürsoy O, Yazar A, Yılmaz Y (20I5) Peynirlerde Bulunan Kan Basıncını Düşürücü Biyoaktif Peptitler. Akademik Gıda I3(3); 237-246.

Guggisberg D, Eberhard P, Albrecht B (2007) Rheological characterization of set yoghurt produced with additives of native whey proteins. International Dairy Journal 17; I353-1359.

Ha E, Zemel MB (2003) Functional properties of whey, whey components, and essential aminoacids: mechanisms underlying health benefits for active people. Journal of Nutritional Biochemistry I4 (5): 25I-258.

Hugunin A, Lucey JA (2009) Whey ingredients in yogurt and yogurt beverages [on line]. U.S. Dairy Export Council, Applications Monographs. Yogurt 2009, pp. I-12. Available at: [http://www.thinkusadairy.org/ Documents/Customer \%20Site/C3-Using\%20Dairy/ C3.7Resources\%20and\%20Insights/03Application \%20 and \%20Technical\%20Materials/ YOGURT_ENG.pdf].

Karagözlü C, Bayarer M (2004) Peyniraltı suyu proteinlerinin fonksiyonel özellikleri ve sağlık üzerine etkileri. Ege Ünv. Ziraat Fak. Dergisi 4I (2); I 97-202.

Korhonen H, Pihlanto-Leppala A, Rantamaki P, Tupasela T (1998). Impact of processing on bioactive proteins and peptides. Trends in Food Science and Technology, 9, 307319.

Kreminski A, GroBhable K, Hinrichs J (20II) Structural properties of stirred yoghurt as influenced by whey proteins. LWT-Food Science and Technology 44; 21342140

Krolyczyk JB, Dawidziuk T, Janiszewska-Turak E., Solowiej B (2016) Use of whey and whey preparations in the food industry-areview. Polland Journal of Food Nutritient Science 66(3); I57-165.
Lagrande $\mathrm{V}$, Whitsett D, Burris C (2015) Global Market for Dairy Proteins. Journal of Food Science 80; SI, AI6-A22.

Mathew BB, Krishna-Murthy TP (2013) Whey-From Waste to Worth. International Global Resaecrh Analysis 2(8), August, 8-9.

Matumoto-Pintro PT, Rabiey L, Robitaille G, Britten, M (20I I) Use of modified whey protein in yoghurt formulations. International Dairy Journal 21: 21-26.

Mleko S, Gustaw W (2002) Rheological changes due to substitution of total milk proteins by whey proteins in dairy desert. Journal of Food Science and Technology 39: I70- 172 .

Özen AE, Kılıç M (2007) Peynir Altı Suyundan Elde Edilen Serum Proteinlerinin Fonksiyonel Özellikleri, Gıda Teknolojileri Elektronik Dergisi 3: 45-49.

Özcan T, Delikanlı B (20I I). Gıdaların Tekstürel Özelliklerinin Geliştirilmesinde Peynir Altı Suyu Protein Katkılarının Fonksiyonel Etkileri. Uludağ Üniversitesi Ziraat Fakültesi Dergisi 25 (2): 77-78.

Pal S, Radavelli-Bagatini S (2013) The effects of whey protein on cardiometabolic risk factors. Obesity Rev. I4: 324-343.

Patocka G, Cervenkova R, Narine S, Jelen P (2006) Rheological behaviour of adiry products as affected by soluble whey protein isolate. International Dairy Journal, I6, 399-405.

Ramos OL, Pereira RN, Rodrigues RM, Teixeira JA, Vicente AA, Malcata FX (2016) Whey and Whey Powders: Production and Uses. In: Caballero, B., Finglas, P., and Toldrá, F. (eds.) The Encyclopedia of Food and Health vol. 5, pp. 498-505. Oxford: Academic Press.

Sousa GT, Lira FS, Rosa JC, de Oliveira EP, Oyama LM, Santos RV, Pimentel GD (2012).Dietary whey protein lessens several risk factors for metabolic diseases: a review. Lipids Health Dis. I I:67.

Shi J, Li D, Zhao W-H (2017) Quality attributes of the set-type skimmed yoghurt containing enzymatic cross-linked or thermal polymerized whey protein isolate. Cyta-Journal of Food I 5(I): 34-40.

Shah NP (2000) Effects of milk-derived bioactives:an overview. British Journal of Nutrition 84:3-10.

Walsh-O'Grady CD, O'Kennedy B, Fitzgerald RJ, Lane CN (200I) A rhelogical study of acid-set 'simulated yoghurt milk' gels prepared from heat-or pressure-treated milk proteins. Lait 81: 637-650.

Yerlikaya O, Kınık Ö, Akbulut N (2010) Peyniraltı suyunun fonksiyonel özellikleri ve peyniraltı suyu kullanılarak üretilen yeni nesil süt ürünleri. Gıda 35(4); 289-296.

Young S (1999) Whey products in cold pack pasteurized processed cheese foods and cheese spreads. U.S. Dairy Export Council, Applications Monograph. Processed cheese. 1999. pp. 1-8. Available at: [http://www.usdec. org/assets/documents/ CustomerSite/C3-UsingDairy/ C3.7-ResourcesandInsights/03-Applicationand TechnicalMaterials/ColdPackPasteurizedCheeseSpreads English.pdf].

Young S (2007) Whey products in ice cream and frozen dairy desserts[on line]. U.S. Dairy Export Council, Applications Monograph,pp. I-12. Ice cream 2007. Available at: [http:// www.thinkusadairy.org/Documents/Customer\%20 Site/C3-Using\%20Dairy/C3.7Resources\%20and\%20 Insights /03Application\%20and\%20Technical\%20 Materials/ICECREAM_ENG.pdf]. 